\title{
The Body Plot: Self-Mastery and the Counter Narrative of Gaskell's North and South
}

\author{
Laura Hayes
}

After the publication of Elizabeth Gaskell's 1855 novel, an unsigned review in the Examiner calls attention to the novel's excessive character descriptions:

We fancy [Margaret Hale] now and then a little too 'superb' in the description. We have too much of her 'curled upper lip,' of her 'lovely haughty curve' of her face, and of her 'round white flexile throat'...We cannot always reconcile the freaks that flit over the surface of her emotion to the depth and truth of the emotion itself. (245)

The copious descriptions of Margaret's body are meant to serve, the reviewer argues, as a guide for the reader to interpret her depth of character. But instead, Gaskell's narrative excess disguises Margaret's feelings. When the reviewer describes the "freaks that flit over the surface," they collapse the face as the speaker of such emotion, and the obvious object of the preposition, with "emotion," offering up syntactically the synonymous implication in Victorian character description. Relying on the assumption that Margaret's description should point to "the depth and truth of emotion itself" in such a novel, Margaret's "freaks" untether her physiognomy from her character, destabilizing reader expectations, and making space in the narrative for unscripted, perhaps freakish, conduct.

Gaskell's writing of this perceived inconsistency in Margaret - what the reviewer considers "a slight drawback from the charm of her character" (245) - asks us instead to read the sequence of Margaret's physical positions, not simply her static features, as indicative of her character. I argue that this approach provides a counter-narrative and a counterplot to the archetypal story of the middle-class Victorian woman, often depicted as weak, quiet, and small. Instead of simply reading her body as a site upon 


\section{IJCS}

which various Victorian ideologies are inscribed because of her status - as a woman, as middle class, as a dutiful daughter, a protective sister, an object of affection-I suggest that Margaret's movements, acutely detailed by Gaskell, "narrate" a parallel and muted plot that releases Margaret from the expectations of Victorian womanhood, to which she finds herself measured by each character in the novel. Rejecting the contemporary science of physiognomy as indicative of character, Gaskell's focus on Margaret's movements posits motion as inherently productive and theorizes movement as self-producing. ${ }^{\text {i }}$ Reaching beyond a critique of gendered spheres, North and South uses physical movement as a metaphor for political movement, and places the middle-class woman as the primary motivation for industrial reform in mid-19 $9^{\text {th }}$ century England.

Margaret's movements have been studied by numerous scholars, specifically regarding her walking in and through compromising spaces, her train travel and engagement with modernity, and her modesty and feminine performance. ${ }^{\mathrm{ii}}$ The overall bearing of this scholarship is a shared attention on the middle-class body that in turn inscribes codes of feminine performance. But little writing has taken up the importance of the novel's interest in Margaret's physicality. In order to read Gaskell as contributing to cultural conversations about the value of women in the stalemate of industrial reform, Margaret's movements cannot simply be read as female agency, but as constitutive of the representation of woman herself. Brian Massumi's study of movement provides a helpful framework for interpreting Gaskell's focus on motion. Cautioning against reading the body for its ideological codes, Massumi argues instead for an understanding of the moving body in terms of potential and possibility that creates a constant indeterminacy. When the body is static, as in character description, it reaches its capacity, but when a body is in motion, it "is in an immediate, unfolding relation to its own non present potential to vary" (Massumi 4). That is, the body creates its "conditions of emergence" through movement, rather than maintaining itself a static site of the emerged (Massumi 10). The novel draws a sharp distinction between emergence and the emerged in its various depictions of Victorian womanhood in the static figures of Margaret's cousin, aunt, and mother. Gaskell accomplishes this paradox of the moving body - as a thing that is not but can be - in writing Margaret's discreetly intentional and constant movements. Though Gaskell's reviewer regards Margaret's changes as "freaks," the novel demonstrates a much more designed change in its heroine. What reads to other characters, as well as to Gaskell's reviewers, as capriciousness creates a narrative tension that allows Margaret the latitude for emergence.

"Movement" usefully terms the interplay among narrative discourse, figural motion, and historical context of the body. In mid-century Britain, Victorian essayists such as Isaac D'Israeli, James Anthony Froude, John Stuart Mill and Thomas Arnold employ the term to discuss social reform. "Movement" became a metaphor for the actions performed by groups of people, generally men, toward a central political goal, and often implied a sort of radicalized popular approach to parliamentary concerns. In Gaskell's mid-century industrial novel, in which social reform is the heroine's primary goal, her movements are twofold as an expression of mobility and as an embodiment 
of change, reform, and, as Wendy Parkins has said, modernity (507). The result is Margaret's emergence on two levels. First, at the plot level, she contradicts her prescribed role by fleeing repeated scenes of stasis, refusing her suitors, and otherwise challenging feminine norms. The second takes place at the narrative level, where Gaskell heavily depends on metaphor. Metaphor allows Gaskell to depict the stasis of normative female behavior in repeated images of sickness and sleep that nearly writes Margaret's female relatives out of the plot. At the same time, metaphor reinforces Margaret's energetic counter-narrative, which aligns individual and national development. That is, Margaret cannot be a social reformer in a marriage plot; she can, however, register the concerns of political movements through her own unfeminine and individualized movements. What results is the presence of a female body, not merely as ideology, but as motion, continually moving, "emerging," in Massumi's words, and folding back through memory, so to emphasize always Margaret's potential.

\section{FORMS OF LEGIBILITY}

In The Women of England: Their Social Duties and Domestic Habits (1839), Sarah Stickney Ellis writes of class distinction:

In looking around, then, upon our 'nation of shopkeepers,' we readily perceive that by dividing society into three classes, as regards what is commonly called rank, the middle class must include so vast a portion of the intelligence and moral power of the country at large, that it may not improperly be designated the pillar of our nation's strength, its base being the important class of the laborious poor, and its rich and highly ornamental capital, the ancient nobility of the land. In no other country is society thus beautifully proportioned, and England should beware of any deviation from the order and symmetry of her national column. (14, emphasis mine)

And in his Sesames and Lilies (1865), John Ruskin will impart a "guiding function" on the middle-class woman, a sentiment that endured throughout the period, its conduct books, and its literature (77). Writing between these moments, Gaskell creates in Margaret a woman who blends "intellectuality and strength with womanly sweetness and playfulness," according to an unsigned review, and is "as strong as an angel of comfort" for her father and brother after her mother's death, according to Gaskell's own narrator ("Review of North and South" 338; 246). It was the middle class that was the "pillar" of the English class system, and the middle-class female body that physically and ideologically reproduced Englishness.

In each location across England, Margaret's body presents itself for participation in Englishness, in womanliness, and always as representative of her middle-class status. And in each location across England, Gaskell troubles the parameters of the womanhood Margaret presumably represents by calling attention to her resistance. First introduced in her wealthy Aunt Shaw's London home, Margaret is rendered 


\section{IJCS}

"passive" and "silent" while the family plans her cousin's wedding (Gaskell 11). And, as if luxury renders London women eternally idle, her cousin Edith sleeps through the wedding preparations, rolling "herself up into a soft ball of muslin and ribbon, and silken curls, and gone off into a peaceful little after-dinner nap" (7). While the refashioning of Margaret's expensive but plain dress only succeeds at the surface level - shawls are draped across her shoulders and then removed - the narrative reduces her cousin to the components of her dress. The sentence transforms Edith into a bride by metaphorically turning her into the material pieces of her femininity, with her silken curls naming the essentializing flourish that makes the figure of the woman a commercial product through Victorian codes of beauty. Edith's sleeping then takes on the additional valence of her unimportance once her life's marriage plot is complete.

Margaret and Edith's familial relationship reinforces Margaret's claim to gentility (her manners and dress, other characters notice, are most refined, even if misunderstood) as well as her relationship with other women. Her aunt, an exaggerated romantic woman, takes on the maternal care of young Margaret and raises her with, though always second to, her own daughter. Mrs. Shaw appears to equal the stately strength of Mrs. Thornton, whom the novel introduces later, but she develops a "nervous little cough" in London that requires an extended trip to Italy (15). Her "pretty" daughter likewise, often sleepy but doting and silly when awake, marks a striking contrast to the "tall, finely made figure" of Margaret (11).

Despite the many moments in which Margaret's finery is measured by wealthy women and working women alike, the narrative capture of Edith's figure in her bridal state becomes the symbol of materialistic womanhood that Margaret attempts to flee. At the beginning and end of the novel, when Margaret resides in London, her aunt's house renders her physically static. During a lively dinner conversation, Margaret plays with her food, "looking grave and absent" (8). She feels "indescribable weariness" and "oppressed" with the flurry of wedding preparations, seeking an earnest conversation with her suitor, Mr. Lennox (13). Margaret stands "passive and silent" when her aunt's friends admire the wedding gift of Indian shawls, and when her aunt finishes admiring the shawls Margaret "sank rather more into the background" (12). Returning to London at the end of the novel after the deaths of her parents, Margaret again returns to a state of passivity. She sleeps in "the nursery of her childhood, just when it merged into girlhood, and when the feelings and conscience had first awakened into full activity" (401). But her aunt curtails this activity when she becomes "bewildered and hysterical" by simply missing a train, and requires the young women to take a daily carriage drive through London when Margaret "longed to walk" $(400 ; 20)$. For Margaret's class, London requires her gentility without the characteristic expressions of benevolence or courage that she exercises in Helstone and Milton. London restricts Margaret to a "type" of womanhood that she eagerly breaks free from in the manufacturing district. Her Aunt Shaw and Edith depend on the wealth and behavior of the men around them to be able to perform their womanhood, which Margaret, "oppressed" by the celebration of this dependence, rejects. 
Taking the place of the bride in wedding preparations, even as she discreetly critiques the wedding celebration, Margaret continuously occupies multiple and divergent modes of femininity. And it is precisely her variability that allows her to play the roles given to her so that while her identity is never stable, it is continuous. Gaskell points to the depth and difference of Margaret's character explicitly in a long physiognomic description of Margaret and her father, showing at once the roles assigned to Margaret and the ways she maneuvers her own indeterminacy:

He smiled back again, but faintly, as if it were an unusual exertion. His face returned into its lines of habitual anxiety. He had a trick of half-opening his mouth as if to speak, which constantly unsettled the form of the lips, and gave the face an undecided expression. But he had the same large, soft eyes as his daughter, -eyes which moved slowly and almost grandly round in their orbits, and were well veiled by their transparent white eyelids. Margaret was more like him than like her mother. Sometimes people wondered that parents so handsome should have a daughter who was so far from regularly beautiful; not beautiful at all, was occasionally said. Her mouth was wide; no rosebud that could only open just enough to let out a 'yes' and 'no,' and 'an't please you, sir.' But the wide mouth was one soft curve of rich red lips; and the skin, if not white and fair, was of an ivory smoothness and delicacy. If the look on her face was, in general, too dignified and reserved for one so young, now, talking to her father, it was bright as the morning, -- full of dimples, and glances that spoke of childish gladness, and boundless hope in the future. (18)

Wrapped in a physiognomic reading of Mr. Hale's tiredness and anxiety, the extensive description of Margaret speaks at once to Margaret's origin and to the relation between her typed performance of femininity and her resistance to it, which presents the conditions for her emergence. Having been raised by her Aunt Shaw in London, the narrative must here establish Margaret's origin, showing her kinship to the quietude of a country clergyman in physical appearance and in anticipation of her family's needs. But despite her likeness to her father, Margaret is set apart from her family, in stereotypical protagonist form, by her simultaneous unlikeness. Margaret's dissimilarities from her parents, here captured in the opposition of their physiognomic differences - her parents "handsome" and she "so far from regularly beautiful" (both terms depending on pre-determined codes the reader must supply) - thematize the difference between Margaret the dutiful daughter and Margaret the independent woman.

Even as the text tells us that she "so far from regularly beautiful," it does not imply that she is not beautiful at all, for the description of her "rich red lips," her smooth "ivory" skin, and a "bright" face "full of dimples" still resonates with Victorian ideas of woman's beauty. Margaret is not merely a negation of the primary term, but the relation between them, in Massumi's formulation (70). With the focus on the wideness of her mouth, the text instead tells us she is not merely beautiful. Instead of whispering the sweetest obedience with a "rosebud" mouth that could only 
open just enough to let out a 'yes' and 'no,' and 'an't please you, sir," the wide mouth is presumed to have the capacity to speak quite boldly in her body's "dignified and reserved" appearance. Concluded by the conditional "if," Margaret's face and figure take on two resonances simultaneously, the "dignified" and "reserved" appearance uncharacteristic for her youth, and the "dimples" and "childish gladness" that bring her ailing father joy. In the relation between these two, here grammatically represented in the conditional and two subsequent clauses, the narrator creates space for her character's divergence, privileging not one version of Margaret, but using the interplay between performances as generative of her movement and change. The if/then structure of the final sentence reverses Margaret's actual growth from childhood to adulthood by filling the latter position with "glances that spoke of childish gladness, and boundless hope in the future." Margaret's character folds back on itself, as it does also when surveying her nursery before her cousin's wedding, reverting to childhood as a means to negotiate her course of action in the present. Rather than the "dignified" and "reserved" woman that effectively marks her growth complete and unattractive, her "dimples" and "glances" portray her potentiality.

Margaret's subsequent refusal of Mr. Lennox, the suitor who follows her to her family's home, can then be read through the divergence of character in Margaret. Twice, Lennox tries to capture Margaret, and twice she responds with motion as her primary positioning. During Lennox's visit, he and Margaret pass time by painting a cottage belonging to an old man. While Margaret speaks to the old man, Lennox sketches both "figures," man and Margaret, into the cottage scene (27). When Margaret sees his sketch she "laughed and blushed" while Lennox "watched her countenance":

"Now, I call that treacherous," said she. "I little thought you were making old Isaac and me into subjects, when you told me to ask him the history of these cottages."

"It was irresistible. You can't know how strong a temptation it was. I hardly dare tell you how much I shall like this sketch.”

He was not quite sure whether she heard this latter sentence before she went to the brook to wash her palette. She came back rather flushed, but looking perfectly innocent and unconscious. He was glad of it, for the speech had slipped from him unawares - a rare thing in the case of a man who premeditated his actions so much as Henry Lennox. (27)

In a moment nearing ekphrasis, Gaskell writes Margaret as Lennox's artistic subject, and briefly, we read Margaret through Gaskell's writing of Lennox drawing her representation. Margaret's blush, and later flush, expresses her discomfort with his ability to capture her figure and possess her likeness. Not only does Lennox render her in stillness, he wishes also to formulate it himself, by later asking her to marry him, which the novel repeatedly shows as a static state for women. Lennox's ability to fix 


\section{Hayes 101}

her form into his sketch is what Margaret tries to avoid by leaving her Aunt Shaw's home in London. Being in Lennox's "frame," metaphorically rendered in the sketch, discontinues the emergence of her character and would narratively require a completed plot, an end to her movements as with her cousin Edith. As with Lennox's proposal, and a later interview with Mr. Thornton, Margaret responds to this forced stillness by leaving the scene. By here giving the frame to Lennox, a character whose intentions result from temptation and whose matrimonial designs have been modeled by Edith's cousin and Captain Lennox, the narrative critiques the restriction of femininity to the material representation of a stationary body.

Therefore, when Lennox proposes and the stillness of her body is made literal, the text renders the interaction as Margaret's subjection to him. He takes "sudden possession of her hand, so that she was forced to stand still and listen" (30). Lennox is not a forceful character, and yet his proposal physically paralyzes Margaret, except for "the fluttering of her heart" (30). Margaret listens, like she must, but "wished herself back with her mother - and her father-anywhere away from him" (30). Despite her wish to flee, Margaret is still and silent. Her hands, though, which Lennox physically captures at the same time he asks for her symbolic hand in marriage, she "firmly striv[es] to extricate...from his grasp" (30). Here the scene of capture is reversed and the figurative becomes the literal: instead of speaking in stillness, Margaret now acts silently but physically, trying to pull her hand from his grasp. In the feminine forcefulness of her hands and her "quivering" lips, Margaret desires to "put an end to it with her high maidenly dignity" (30). But she misunderstands that it is her "maidenly dignity," a finite and measurable quality, which Lennox seeks.

His proposal is the first of many instances wherein Margaret is considered what Barbara Leigh Harman calls, "the object of universal regard," and initiates the shame associated with the middle-class female body (189). As Harman notes, to be "universally regarded" is to be seen unhindered: "when a middle-class woman took to the public stage," as an object of regard, "she brought her body, ordinarily confined to the drawing room, before the eyes of others" (369). For Margaret, as depicted in Lennox's painting and proposal, to be set before the eyes of others means losing control of how the self and explicitly one's body is perceived. After Lennox's proposal, Margaret returns to her family's home to speak to her father, feeling "guilty and ashamed of having grown so much into a woman as to be thought of in marriage" (34). Margaret's shame interferes with her filial relations because it exposes the sides of her divergent self to one another, making the conditional determinate and therefore creating a "certain instability in her own subjectivity" (Parkins 510). Shame creates the "recognition" of self as the object that another sees and judges. To see oneself as seen by others is to recognize oneself as an object, and to acknowledge that when one is as the other sees them to be is to identify the self as the object the other sees.iii Shame's violence is marking the body as static, as complete, and made so by another. The "instability" of Margaret's subjectivity that leads to her shame is, paradoxically, a result of being forced into stability. Margaret's shame is a product of "having grown so much into a woman," a past perfect description which thematically places her completed growth — resulting in the static occupation of a wife, like Edith, Mrs. Shaw, 
and her mother - as a foregone conclusion. Margaret's refusal then requires not simply a "yes" or "no" or "an't please you, sir," as the early description of her visage tells us, but a resounding self-mastery in her voice and body that allows Margaret to upset the types of womanhood in which Lennox's sexual desire or her father's nostalgia place her.

\section{PRECARIOUS MOTIVATIONS}

Margaret's variability, shown just beneath the surface of her character in London and Helstone, nearly approaches a traditional binary of the womanly/unwomanly that Gaskell refuses to entertain. Instead, Gaskell posits movement, and specifically female movement, as rerouting traditional codes by which character is understood. But when Margaret moves to Milton-Northern, her variability through movement manifests itself in her use of space as Gaskell dismantles the binary of the public/private. Critiques of the public/private divide are numerous, even despite historical evidence proving that it existed more as an ideological parameter rather than a cultural reality. ${ }^{\text {iv }}$ Still, Gaskell takes pains to expand Margaret's emergence through depictions of her moving through large unregulated spaces.

As Margaret moves through her industrial city, she appears as a foreigner who misperforms and whose performances are misread. Her movements become larger as she walks through the city talking to strangers, manages her father's accounts, and participates in discussions of rights and reform. The space Gaskell gives Margaret in Milton-Northern becomes not merely variability, but potential, or "the modification of space" (Massumi 75). Margaret's emergence depends on movement over space, which takes place in the form of events (speaking with Mr. Thornton, the riot scene, the return of her brother, the death of her mother) that suspends her, in Massumi's words, in the being of relation (70). When entering Milton-Northern, these events hold Margaret in relation so that she emerges only through movement among them. Milton-Northern, written as a sequence of events of this being of relation, advances a field of potential for Margaret, out of her "modification of space," or how her movement through spaces as a relation among them, "modifies the distribution of potential movement" (Massumi 75). The novel's very title (and multiple chapter headings) capture the potential of Margaret's relationality in the coordinating conjunctions North and South, "Doubts and Difficulties," "Masters and Men," "Men and Gentlemen." Despite the dichotomy the novel posits, and the nearly dialectical synthesis it implies, the characters and Margaret specifically largely remain in the relational term "and," residing between the north and the south, arbitrating the relations between master and men, and clinging to the term "gentlewoman" when repeatedly faced with the falsity of "men and gentlemen."

In order to make meaning out of these relations or the modifications of space they enable, space must be determined by parameters in which movement takes place, again built into the novel's structure. To conceptualize representations of movement in narrative space, feminist, dance, and performance studies offer the term "choreography," that speaks to the interaction of figural movement, corporeal 
representation, and narrative discourse. In "Choreographies," his interview with Christie V. McDonald, Derrida speaks of the need to textually record a proliferation of voices, "for a chorus, for a choreographic text with polysexual signatures" (76). The polychoral model Derrida posits evades the parameters of sexual difference by following his first "Geschlecht" essay, in which he puts forth sexual neutrality as an apparent asexuality. What he calls the "double dissymmetry" of sexual difference in "Choreographies" produces not asexuality but what "would be sexual otherwise: beyond the binary difference that governs the decorum of all codes, beyond the opposition feminine/masculine" and beyond all other sexual identities (76). ${ }^{\mathrm{v}}$ Choreography becomes necessary to define the ways in which "the masses, this indeterminable number of blended voices, this mobile of non-identified sexual marks ... can carry, divide, multiply the body of each "individual," whether he be classified as "man" or as "woman" according to the criteria of usage" (Derrida 76). In this formulation, Derrida decenters the individual for her place of relation that results the process of individuation rather than the mapping an individual. "Choreographic" here allows Derrida to simultaneously refer to vocal and physical multiplicities ("choreo"), the visual and written codes that represent the emergence of these multiplicities ("graphic," and "graphy") and the "writing of the dance," which is the process of individuation ("choreography").

Massumi's proposition that movement results from the being of relation then follows Derrida's formulation of individuation as a necessary alternative to locating bodies on a "grid" according to social markers or to place people according to a “"geography' of culture" (Massumi 2-3). In North and South, while characters around Margaret repeatedly attempt to locate her on an ideological "grid" according to her sex, her dress, and her conduct, Margaret's movements bespeak her own investment in the relation of multiplicities that creates the conditions for individuation. For the novel's narrator, self-mastery defines Margaret's growing sense of her own identity in specific spaces and according to her performance of certain ideologies and stands explicitly in opposition to a master of men, the owner of space and the means of making space, the capitalist Mr. Thornton.

When Mr. Thornton enters the novel as a "master" of his workingmen and a gentleman, he appears to be no equal for Margaret's own growing sense of mastery. Both characters are fiercely private; they both have remade themselves from painful pasts (hers painful to leave, his to live); she refuses to shake his hand, which they both culturally misunderstand; and they remain, for the length of the novel, positioned across and figuratively against one another when speaking or listening. Upon their first meeting, Margaret enters the room "with the straight, fearless, dignified presence habitual to her," instantly assuming "some kind of rule over him" (62-63). The scene that follows plays between Mr. Thornton's attempt to place Margaret figuratively as a woman, first thinking she is a young girl, then taking surprise at her command, as well as literally deciding on the correct house for the family to occupy, and Margaret's overt resistance to his reading. Mr. Thornton notices her "beautiful countenance" that does not "flush" with "surprise" when seeing him, and further, as the text focalizes Margaret's movements through Thornton's perception, admires her "superb ways of 
moving and looking," "the manner of carrying her head, her movements, full of a soft feminine defiance" (63). Margaret's "feminine defiance" disallows Mr. Thornton from reading her as a static image, as Lennox tries to do, and instead, the narrator records her constant micro-motions:

She sat facing him and facing the light; her full beauty met his eye; her round white flexible throat rising out of the full, yet lithe figure; her lips, moving so slightly as she spoke, not breaking the cold serene look of her face with any variation from the one lovely haughty curve; her eyes, with their soft gloom, meeting his with quiet maiden freedom (64).

An unusual character description, it relies on Margaret's actions rather than her features to explain her character. Further, the present tense verb forms leave her always "rising," "moving," and "meeting" so that she seems to always grow larger while the narrative relegates Mr. Thornton merely to a pronoun. The result is Mr. Thornton leaving Margaret feeling "more awkward and self-conscious in every limb than he had ever done in all his life before," when he had originated the gaze (65).

The scene of Margaret's embodied self-mastery, characterized by the use of action verbs in a static description, is then set against their next encounter in which Mr. Thornton joins the Hale family for tea and the men discuss business, a conversation Margaret takes no interest in and Gaskell does not record. While they speak, the narration follows Margaret's "pretty, noiseless daintiness" as she prepares the tea:

She had a bracelet on one taper arm, which would fall down over her round wrist. Mr. Thornton watched the re-placing of this troublesome ornament with far more attention that he listened to her father. It seemed as if it fascinated him to see her push it up impatiently, until it tightened her soft flesh; and then to mark the loosening - the fall. He could almost have exclaimed - 'There it goes, again!' (80).

The repetitive sequence of replacing the bracelet only to have it fall again captures the maddening choreography of female performance. Margaret's silent service in the tea preparations locate her in relation to her family duties and appropriate public behavior. Again, however, Mr. Thornton becomes mesmerized by her movements, here circuitous and predictable as the bracelet falls and she replaces it on her arm "until it tightened her soft flesh." Euphemistically, the tightness of her flesh under the small bracelet appeals to Thornton's desire for Margaret while at the same time she serves her father tea in the family circle. Gaskell then displaces his sexual desire for Margaret onto the object that makes her move. The movement of the bracelet and of her hand in response, not the tightness of her flesh, become the central images of the scene.

In the same way, Mr. Thornton displaces his desire to touch her hands in watching their utility. He watches Margaret serve sugar to her father, who "took her little finger and thumb in his masculine hand, and made them serve as sugar-tongs" (80). 
Observing her delight, Mr. Thornton "almost longed to ask her to do for him what he saw her compelled to do for her father" (80). Fascinated by Margaret's smallest movements, Mr. Thornton remains intensely aware of the distance between his own body and hers. She lifts her "beautiful eyes" to her father, "full of light, half-laughter and half-love," but she "handed him his cup of tea with the proud air of an unwilling slave" (80). As the conversation continues, Margaret "drew into a corner, near her mother" and away from Mr. Thornton to increase their physical distance, despite "the attraction they evidently felt towards each other" (81).

Terence Wright suggests that the repeated scenes of description explicitly related to Margaret's femininity are integral to Gaskell's representation of "all woman," or the very essence of womanliness (103). However, as I've suggested, Margaret's unrehearsed movement displaces her as a linchpin of Victorian ideology and unsettles the narrative codes by which readers are trained to understand her femininity. Though the narration relentlessly calls attention to Margaret's fleshliness, she persists in walking unchaperoned through Milton, completing domestic business by herself, and resisting every advance of her capitalist suitor. But Gaskell is not entirely supportive of unrestrained movement. For it is in a moment of Margaret's most shameless selfmastery, and her clearest arbitration of political turmoil, that Gaskell calls attention to the dangers of her physicality.

Margaret's physical appearance draws the attention of capitalists and working men alike, who, when she walks alone, "commented not on her dress, but on her looks" (72). Margaret's refinement and, to the northern mind, strangeness become a cultural barrier that she wears on her body. Her fine clothes, noticed by factory women and later Bessy Higgins, and her appearance, already noted by Mr. Thornton and the working men, make her body the barrier between wealth and work that saves Mr. Thornton during the riot. While Margaret walks through the streets, the novel suggests that her agency exposes her to danger in the form of the "disorderly tumult" of working men (72). Gaskell calls attention to Margaret's body, emphasizing her "maidenly dignity" and her "finely made figure" that she reiterates through her movements $(30 ; 11)$. For her to be appropriately self-sacrificing in the scene of the riot, as well as convincingly desirable to Lennox and Thornton, she must stand out for her foreignness in the northern way of life. Out of "fright" comes Margaret's "indignation," but these men initially never threaten violence, only a rough admiration (72). In these scenes Margaret flees to "the quiet safety of her home" where she becomes "amused" if "irritated" by the men's comments (72).

The scene of harmless, admiring workers on the street is then explicitly juxtaposed to the riot at Mr. Thornton's mill, wherein Margaret leaves the safety of Thornton's home to shield him from an angry mob of workers with her body. Margaret implores Mr. Thornton to "speak to your workmen as if they were human beings," but Thornton, ever intent on exerting his authority over his men, intends to handle the mob by (lawful) violence (175). Margaret, shielded from the relations between master and worker in her daily domestic life, misunderstands the consequences of her request. Notable here is the depiction of the unified working-class body, not bodies - multiple, distinct representations of the physical existence of the lower classes - but a "crowd," 
"cruel and thoughtless, - cruel because they were thoughtless; some were men, gaunt as wolves, and mad for prey" (176). The thoughtless crowd stands physically opposite of the individual body and internal consciousness of Margaret. As she places herself between Mr. Thornton and the mob she asserts herself by proclaiming, "For God's sake! do not damage your cause by this violence. You do not know what you are doing" (177). When her speech and reason fails, however, and when one indeterminate person in the mob throws a pebble at Mr. Thornton and Margaret, she lays "like one dead on Mr. Thornton's shoulder" (177). The novel paints Margaret's movement as an act of passion, which Mrs. Thornton and other characters read as her regard for Mr. Thornton. By flinging her body over Mr. Thornton's, and by him "encircling" her in his arms, she appears to momentarily lose her classed gentility. The narrator also criticizes Margaret's thoughtless actions, "if she thought her sex would be a protection ... she was wrong" (177). For young Margaret, actor as she is, witnesses only the social conditions of the working poor, not the economic conditions that enforce inequality.

Nearly in the center of the novel, and Margaret at the center of the scene, we observe the body of the middle-class woman as a Christ figure, offering her life for the sins of the people. She offers herself as the mediator and her body bears the violence of the confrontation between master and man for the intended ratification of economic inequality in industrial capitalism. Importantly, neither her body nor her voice can ease the anger of the working-class crowd, but her sacrifice and her injury halt the uproar. Until Margaret is hit by the rock, Mr. Thornton refuses to appeal to the workingmen's reason; once she falls into his arms, however, he chastises them: "when a woman comes before you, to ask you for your own sakes to be reasonable creatures, your cowardly wrath falls upon her!" (178). As Mr. Thornton speaks, the men watch "open-eyed and open-mouthed, the threat of dark-red blood which wakened them up from their trance of passion" (178). Deirdre David reads this scene as the "symbolic rape of the middle-class woman," and notes that the image of rape suggests that the "protectress of middle-class ideals" comes under attack by the threat of the working classes (41-42). The blood running (presumably on her forehead, though the text only tells us later) becomes important in symbolizing not only Margaret's "womanly selfsacrifice," but the "political incursion" displaced into "sexual violation" (David 4142). Seeing Margaret's sacrifice, the men are "moved to rational action" (David 43). Key to this reading is the suggestion that working-class men, when chastened by woman's suffering, "shows them to be susceptible to conventional middle-class notions about protection of woman (and therefore capable of moral regeneration by proper middle-class leadership)" (David 43). Margaret's cooperation in this scene, as uninformed as she may be, becomes the impetus of the reform. Representative of middle-class ideology, and made unconscious by the violence of the working classes, the image of Margaret's injured body conveys to middle-class readers, in David's reading, that sacrifice leads to rational reform and to mutual understanding between classes: 
The sight of that pale, upturned face, with closed eyes, still and sad as marble, though the tears welled out of the long entanglement of eyelashes, and dropped down; and, heavier, slower plash than even tears, came the drip of blood from her wound. Even the most desperate ... drew back, faltered away, scowled, and finally went off, muttering curses on the master, who stood in his unchanging attitude, looking after their retreat with defiant eyes. (Gaskell 178)

The sustained implication of sexual violence in Margaret's "pale, upturned face" and the "dark-red blood" coming from an unlocated wound mediates the scene. Her body bridges their sensibilities as it physically divides them.

The problem of Margaret's self-mastery, the novel suggests, is her continued vulnerability to sexual violation. To such a great extent does the novel consider this ramification of female movement that the climax of the plot depends on the perception of Margaret's chastity. The movement that characterizes modernization in MiltonNorthern - a city full of laborers with genteel families in the suburbs - nevertheless conflicts with traditional ideas of Victorian femininity that directly bear on the perceived value of Margaret's body. When Margaret lies to a policeman about walking her brother to the train station, news spreads and eventually reaches Mr. Thornton that she walked out late with an unknown suitor. Margaret can choose to perjure herself by admitting that she lied to the law or she must accept a stain on her maidenly reputation. What begins as private perjury becomes, twisted through the novel's plot, a public charge against her chastity - an intimate part of her feminine identity. Margaret's concern for her brother's safety initially keeps her from clarifying the misunderstanding, and she remains silent in her pride. Margaret's desire to participate in the "public sphere" conflicts with male anxieties about female public appearance, even though she walks with an appropriate chaperone (Harman 351). At this point in the novel, Margaret reaches the limits of space. The novel catches Margaret in the development of her feminine identity (though not in her performance of femininity) by dwelling on the inherent paradox in female potentiality. Despite the multiplicity of relations in which Margaret positions herself toward her individuation, the novel cautions that a woman may only exist in predetermined spaces, the transgressions of which threatens her very potentiality. For what is a middle-class Victorian woman without her chastity? Amid Gaskell's dismantling of spheres, the ontology of sexual difference resurfaces as a primary issue. For a woman, the activity of walking at night becomes more dangerous, as Parkins writes: "What Thornton had interpreted as traditional - if unsanctioned - form of social behavior (a courting couple walking at dusk) was in fact a much more mundane modern pastime (waiting for a train); punctuality, not morality was the issue" (516). The train platform, with its implication of elopement and escape, attaches itself to Margaret's final conversation with her brother and undermines her maidenly dignity, which gave her, for the length of the novel, the motivation for her emergence.

Because of the novel's emphasis on Margaret's movements that for a time ruin her dignity, Margaret leaves Milton-Northern as an effective retreat but an explicit refusal of stasis or loss. Chaperoned by Mr. Bell and her Aunt Shaw in turn, Margaret 
travels to the places of her childhood: Helstone and London, respectively, which allow her memory to continue propelling her emergence as the character folds back on the terms that lead her to her current positioning. Margaret leaves Milton when her father dies, with misunderstanding haunting her relationship with Thornton. She sees Helstone again, but no longer with the picturesqueness of southern living. Finally, she settles in London with her aunt, as propriety would necessitate, but insists on small acts of independence such as buying gowns or caring for Edith's child. All the time barreling us toward a romantic conclusion, however, the narrator and Margaret's thoughts remain on her misunderstanding with Thornton. Margaret attempts "to comfort herself with the idea that what [Mr. Thornton] imagined her to be, did not alter the fact of what she was" (390). The conclusion then, in which they both see each other for who they can become, literalizes the message of reform and understanding on a domestic scale. Discussing her financial investment in Marlborough Mills after she receives Mr. Bell's inheritance, Mr. Thornton speaks her name. His voice "arrests" her "heart pulse" and she "trembles with tender passion" (424). Margaret looks at Mr. Thornton, and then veils her eyes by dropping her face into her hands. He steps closer to her and repeats her name. In another fleshly scene, Gaskell writes: "Still lower went the head; more closely hidden was the face, almost resting on the table before her. He came close to her. He knelt by her side, to bring his face to a level with her ear; and whispered - panted - out the words" (424). He exclaims her name a third time and Margaret turns, her face "still covered with her small white hands, toward him, and laid it on his shoulder, hiding it even there; and it was too delicious to feel her soft cheek against his, for him to wish to see either deep blushes or living eyes. He clasped her close. But they both kept silence" (424). The passion of their intellectual disagreements manifested in physical attraction is, quite explicitly, a trope of the novel genre that allows disunity or miscommunication to resolve itself in physical and emotional union. It is a domestic choreography that prescribes how male and female lovers relate their desires to one another. Yet in a novel that concerns itself with a woman's indeterminacy through the capacity of her movements, this conclusion seems to offer more than is initially apparent.

Many scholars since the publication of the novel have dismissed the conclusion as unfitting or unbelievable for an industrial novel. Parkins dismisses the conclusion as conventionally heteronormative and inconsistently requiring marriage for a heroine who has explored nontraditional female roles throughout the text (517). Pearl Brown, as well, laments the conventionality of the ending: "Margaret will have no effective way to separate herself from her domestic roles and to create an independent life for herself' (354). Other scholars, such as Sally Shuttleworth, Deirdre David, and Judith Lowder Newton find the conclusion unsatisfactory in its suppression of industrial frustration for the harmony of domestic sanctity. The question for these scholars is not so much the conventionality of marriage, or on the affection of Mr. Thornton and Margaret, as it is the conclusion's resistance to taking a stance on a social problem in an industrial novel.

I, however, read the conclusion more generously. The conclusion humanizes Mr. Thornton, as Raymond Williams has said, as a mill owner and capitalist, and 
Margaret's legacy allows Mr. Thornton to enact his humanity (92). Elliott argues that the novel suggests an answer to social problems by its distinct unconventionality. Reading Margaret's movements allows her husband, the capitalist who is newly committed to social reform, to marry the movement, or change, that Margaret consistently embodies. The union of the two characters proposes a new social sphere in which the capitalist wife and husband, who (will) share a residence in Marlborough Mills - a locus of Manchester production - metaphorically, almost allegorically, presents an alternative to the public/private division of male and female labor and to the womanly/unwomanly dichotomy (49).

Further troubling the critique of a conventional conclusion, the marriage proposal is both a moment of passion and a moment of shame for Margaret, who, implored by Mr. Thornton to lift her head, "slowly faced him, glowing with beautiful shame" (424). The conclusion of the novel allows Thornton the first glimpse of Margaret that does not solely rely on her movement, and she is therefore filled again with shame. Yet by his proposal, Thornton calls Margaret into movement, rather than capturing her and prizing her stillness, as the marriage with Lennox she rejected, implying their continued participation in social movements. For this reason, one early critic writes that the love between Mr. Thornton and Margaret is "very cold, very English" ("Revue des Duex Mondes" 364), which seems unconvincing in a conventional marriage plot. Yet, it seems to be this very conventionality that Gaskell embraces in the genre of the industrial novel to question the position of the middle-class woman and the woman's body who is often depicted as static despite her occupation of reproducing nationality. Margaret, a middle-class woman, has instead become a capitalist, her movements speaking to her essential productivity. ${ }^{\mathrm{vi}}$

The marriage plot allows Gaskell to remain within the framework of a genre that in many ways pushes at the edges of female identity. Here, I have located Margaret's identity - her own understanding of it as well as the perception of others - in her body. One precise problem, however, for the bourgeois woman was her embodiment (Parkins 516). All the novel's characters attempt to position Margaret according to their ideological expectations: Mr. Lennox, Mr. Thornton, the working men, and Margaret herself encode her body as an object of desire because of her beauty, her feminine performance, and her ultimate social need to be married, while the working women, her Aunt Shaw, and her cousin Edith look on it commercially because of her clothing, her ability to marry wealth, and eventually her inheritance. Our narrator implies both but insists on Margaret's variability. That is, Margaret never precisely is but remains the embodied idea of potential. Wright argues that Gaskell "had a special and peculiar concern with the nature of women, both historically and biologically," and Gaskell indeed expresses sympathy toward Margaret's bodily experience as an alternative way of expressing female selfhood (9). Margaret worries about her maternal potential while playing with Edith's child while at the same time she has grown into mature, independent womanhood, investing her fortune, and traveling across England. Parkins concludes that Gaskell's novel is one championing female agency, tying her argument to Gaskell's agency also as a middle-class woman who explored her boundaries of the public/private sphere through writing political novels 
(D’Albertis 46). By creating a character with self-mastery, who moves freely, embraces modernizing changes, becomes a capitalist, and finally marries on her own terms, Gaskell pushes against the public restrictions imposed on the middle-class woman and on the woman's body, dismantling the dichotomies by which woman is understood as either the half or negation of a binary. Margaret's wardrobe as well as her misunderstanding of social, political, and economic matters make her complicit in the wrongdoings of industrialism. But at the same time, as an independent and mobile woman, she is at the center of industrial reform.

\section{Notes}

${ }^{i}$ The significance of physiognomy to the Victorian public has been taken up in recent scholarship by Sharrona Pearl and Lucy Hartley, who argue that physiognomy provided a way of reading the body and fictional representations of the body as a semiotic system. Pearl argues that it became a strategy by which the public learned to quickly evaluate and taxonomize the personalities and intentions of others in the new and crowded public spaces of the nineteenth century. While physiognomy focused on intrinsic qualities such as the shape of one's face and features, pathognomy judged extrinsic factors, such as expressions and movements that people presumably could control but whose performance still lead the body's reader to foregone conclusions about the individual.

ii See Rosemarie Bodenheimer, Wendy Parkins, Terence Wright, and Barbara Leah Harman.

iii I take my definition of shame from Sandra Lee Bartky and Jean-Paul Sartre, who posit that shame is not merely an experience of embodiment but an ontological register of being and a primary mode of female attunement.

See Bartky Femininity and Domination: Studies in Phenomenology (Routledge, 1990), 85; and Sartre Being and Nothingness translated by Hazel E. Barnes (Washington Square Press, 1984), 350.

${ }^{\text {iv }}$ See Sally Shuttleworth's Introduction to North and South, Deirdre David, and Judith Lowder Newton for critiques of the social and domestic spheres in North and South. And see Leonore Davidoff and Catherine Hall's Family Fortunes: Men and Women of the English Middle Class 1780-1850 for a comprehensive study of the difference between ideology and practice of gendered "spheres" in the Victorian middle classes (Hutchinson, 1987).

v The "double dissymmetry" of sexual difference comes first from the "certain dissymmetry" that is "the law both of sexual difference and the relationship to the other in general" compounded by the "doubly, unilaterally inordinate, like a kind of reciprocal, respective, and respectful excessiveness" (154). To reach through Heidegger's relative silence on the subject of sexual difference, Derrida reads the "forms and determinable contours" of the "non-said" to find that, for Heidegger, neutrality itself structures the binary of sexual duality (69). If sexual difference is an ontological category, that difference would necessarily be essential to the 
beings in question. Resisting an essentialist assumption, but acknowledging a difference, Derrida employs the "negativity" and "positivity" emphasized in Heidegger's language that labels Dasein's relation to sexual duality as negativity, or a "not yet," and Dasein's relation to its "power of essence," or its metaphysical state, as "originary positivity" (71-72). This leads Derrida to conclude that Heidegger considers sexual duality in the determinateness, rather than essence, of Dasein's body.

${ }^{v i}$ Bodenheimer notes that concluding the novel with the creation of female paternalist is not without its problems and remains "an important concept in the imaginative struggle with industrial capitalism" (68). The female paternalist is a "formal indicator" of mediating classes in new industrialism as well as responsible for splitting "moral and social power" (68). But, Bodenheimer notes, Gaskell deconstructs the "parental metaphor" of paternalism to show the necessity of cultural and ideological reform (54).

\section{Works Cited}

Bodenheimer, Rosemarie. The Politics of Story in Victorian Social Fiction. Cornell University Press, 1988.

Brown, Pearl. "From Elizabeth Gaskell's Mary Barton to her North and South: Progress or Decline for Women?" Victorian Literature and Culture, vol. 28, no. 2, 2000, pp. 345-358. JSTOR, DOI:10.1017/S10601. Accessed 16 March 2016.

D'Albertis, Deirdre. Dissembling Fictions: Elizabeth Gaskell and the Victorian Social Text. St. Martin's Press, 1997.

David, Deirdre. Fictions of Resolution in Three Victorian Novels: North and South, Our Mutual Friend, Daniel Deronda. Columbia University Press, 1981.

Derrida, Jacques. "Geschlecht: Sexual Difference, Ontological Difference." Research in Phenomenology, vol. 13, no. 1, 1983, pp. 65-83.

---"Interview: Choreographies: Jacques Derrida and Christie V. McDonald." Diacritics, Vol. 12, No. 2, 1982, pp. 66-76. JSTOR, DOI: 10.2307/464681. Accessed 1 Oct. 2017.

Ellis, Sarah Stickney. The Women of England Their Social Duties and Domestic Habits. London, 1839. HathiTrust Digital Library, hdl.handle.net/2027/uc1.b3121581. Accessed 1 May 2014.

"Émile Montégut on North and South, from an article, the Revue des Deux Mondes." Elizabeth Gaskell: The Critical Heritage. Edited by Angus Easson. Routledge, 1991. Pp. 354-366.

"From an unsigned review of North and South, the Manchester Weekly Advertiser." Elizabeth Gaskell: The Critical Heritage. Edited by Angus Easson. Routledge, 1991. Pp. 337-338.

Gaskell, Elizabeth. North and South. 1855. Ed. Patricia Ingham. Penguin, 1995.

Harman, Barbara Leah. "In Promiscuous Company: Female Public Appearance in Elizabeth Gaskell's North and South." Victorian Studies, vol. 31, no. 3, 1988, pp. 351-374. 
Hartley, Physiognomy and the Meaning of Expression in Nineteenth-Century Culture. Cambridge University Press, 2001.

Massumi, Brian. Parables of the Virtual: Movement, Affect, Sensation. Duke, 2002.

Newton, Judith Lowder. Women, Power, and Subversion. University of Georgia Press, 1981.

Parkins, Wendy. "Women, mobility and modernity in Elizabeth Gaskell's North and South." Women's Studies International Forum, 27, 2004, pp. 507-519. Elsevier, doi:10.1016/j.wsif.2004.09.006. Accessed 16 March 2016.

Pearl, Sharonna. About Faces: Physiognomy in Nineteenth-Century Britain. Harvard University Press, 2010.

Ruskin, John. Sesames and Lilies. 1865. Ed. Deborah Epstein Nord. Yale University Press, 2002.

Review of North and South, by Elizabeth Gaskell. Examiner, 21 April 1855, pp. 244-245. British Periodicals, search.proquest.com/docview/9435806?accountid=14663. Accessed 18 Nov. 2017.

Shuttleworth, Sally. "Introduction." North and South. 1855. Ed Angus Easson. Oxford University Press, 1998.

William, Raymond. Culture and Society 1780-1950. Harper \& Row, 1958.

Wright, Terence. Elizabeth Gaskell: 'We are not angels.' St. Martin's Press, 1995. 